\title{
The Impact of PH on Corrosion Rate in Electrical Assisted Oil Recovery (EAOR) Application
}

\author{
Anthony Kurnia Jaya \\ PT. LAPI ITB, Kota Bandung
}

\section{INFORMASI NASKAH}

Diterima: 19 Nopember 2020

Direvisi: 2 Februari 2021

Disetujui: 18 Februari 2021

Terbit: 30 Juni 2021

Email korespondensi:

anthonykurniaj@gmail.com

Laman daring:

https://doi.org/10.37525/

$\mathrm{mz} / 2021-1 / 267$

\begin{abstract}
ABSTRAK
Korosi adalah masalah yang umum dijumpai pada lapangan minyak dan gas bumi. Dalam proses operasinya, perubahan $\mathrm{pH}$ pada sumur sangat mungkin terjadi dan dapat memperparah kondisi korosi. Pada sumur konvensional, $\mathrm{pH}$ akan memberikan dampak bagi korosi dengan tren tertentu.

Sebagai salah satu metode baru dalam meningkatkan produksi minyak, Electrical Assisted Oil Recovery (EAOR) memberikan hasil yang menjanjikan. Akan tetapi, keberadaan listrik dapat memperparah kondisi korosi di sumur. Oleh karena itu, studi ini akan melakukan penelitian mengenai dampak $\mathrm{pH}$ terhadap sumur yang menggunakan EAOR. Untuk mendukung hasil penilitan, terdapat studi kasus yang dilakukan dengan menggunakan 8 pasangan sumur yang terdiri atas 8 sumur katoda dan 5 sumur anoda. Untuk mengamati hasilnya, studi sensitivitas dilakukan dengan nilai $\mathrm{pH}$ antara 6.5-8.0. Hasilnya menunjukan bahwa terdapat pengaruh juga dari $\mathrm{pH}$ terhadap laju korosi pada sumur yang menggunakan EAOR, tetapi memiliki model yang berbeda.
\end{abstract}

Kata kunci: Electrical Assisted Oil Recovery, Listrik, Laju korosi, $\mathrm{pH}$

\section{ABSTRACT}

Corrosion is a common problem that occurred in oil and gas field. In operating the well, the possibilities for $\mathrm{pH}$ changes is very high that could give a very dangerous impact to the corrosion. In the conventional well, $\mathrm{pH}$ will give an impact to the corrosion rate in a specific trend.

As one of the new method in enhancing the oil production, Electrical Assisted Oil Recovery (EAOR) could give a promising 
result. However, the existence of electricity in this method could worsen the corrosion condition in a well. Therefore, this paper will make a research to determine the impact of $\mathrm{pH}$ in an EAOR well. This study is supported by a case study on oil field that use EAOR method in Indonesia. The case is having 8 pair wells which contains of 8 cathodes and 5 anodes. To observe the effect of $\mathrm{pH}$, a sensitivity analysis is conducted with $\mathrm{pH}$ values ranging between $6.5-8.0$. The result shows that there also an impact from $\mathrm{pH}$ to the corrosion rate in $E A O R$ well but it shows a different pattern.

Keywords: Corrosion rate, Electrical Assisted Oil Recovery (EAOR), Electricity, $p H$

\section{INTRODUCTION}

The corrosion phenomenon in oil and gas industry could take up to $25 \%$ of total failures in the operation process (Kermani \& Harrop, 1996). If the problem couldn't be maintained, the possibility of leakage in casing or tubing will be increased. The further impact is this leakage could be really harmful for the environment and could reduce the production rate in the well.

In the oil and gas field, corrosion is occurred by the existence of carbon dioxide $\left(\mathrm{CO}_{2}\right)$, hydrogen sulphide $\left(\mathrm{H}_{2} \mathrm{~S}\right)$, oxygen and water formation. The other component also could give an impact to the corrosion rate. However, in this study, it will be focused on discussing the corrosion rate that comes from $\mathrm{CO}_{2}$.

Currently, the oil and gas still contribute on a total of $63 \%$ of energy source in the world (Smil, 2017). In order to fulfill the energy demand from oil and gas, a new method in enhancing the production is invented. One of the new method is Electrical Assisted Oil Recovery (EAOR). The concept of this method is by introducing electrokinetic phenomena on the reservoir fluid (Amba,
Chilingar, \& Beeson, 1964). This phenomena will help to reduce the viscosity of the oil and help to improve the production rate. The electricity type that is used in this method is direct current.

Even though this method have a cheaper cost and give a less environmental impact, but the existence of the electricity could give an impact to the corrosion rate. A research by Taxen (Taxen \& Kimab, 2011) shows that the introduction of electricity in a pipeline system with hydrocarbon flow could impact the corrosion rate up to 70 times with $5 \mathrm{~V}$ and $10 \mathrm{~mA}$ of electric.

As enhancement method commonly implemented in a mature field where the corrosion already occur, the existence of electricity could worsen the corrosion condition.

$\mathrm{pH}$, as a parameter that could give an impact to the corrosion, might changes during the production process. This might be occur due to the precipitation between flowing fluid with the rock properties. In addition, the well stimulation process which introducing acid to the well could give a high impact on $\mathrm{pH}$ changes. Theoretically in conventional well, the lower $\mathrm{pH}$ value, the higher corrosion rate will occur. This is caused by acid reaction that enhance the corrosion process.

Even though the $\mathrm{pH}$ impact on corrosion in conventional well is clearly shown, there still lack of research that determining the impact of $\mathrm{pH}$ in EAOR well. Therefore, this study will try to observe and determine the impact of $\mathrm{pH}$ on EAOR well. In observing the $\mathrm{pH}$ impact in EAOR well, there are a case study provided which the data come from an oil field in Indonesia that already make a pilot project for EAOR method. The corrosion model will use the method from ASTM G1 $(\mathrm{G} 1,1999)$. 


\section{BASIC THEORY}

\section{A. pH impact}

At a low $\mathrm{pH}$ condition, corrosion that occur might not produce a protective layer. With the existence of turbulent flow, the transportation of species towards and away from the metal surface will lead to an increase of corrosion rate (Nesic \& Sun, 2010) which is shown in Figure 1 below.

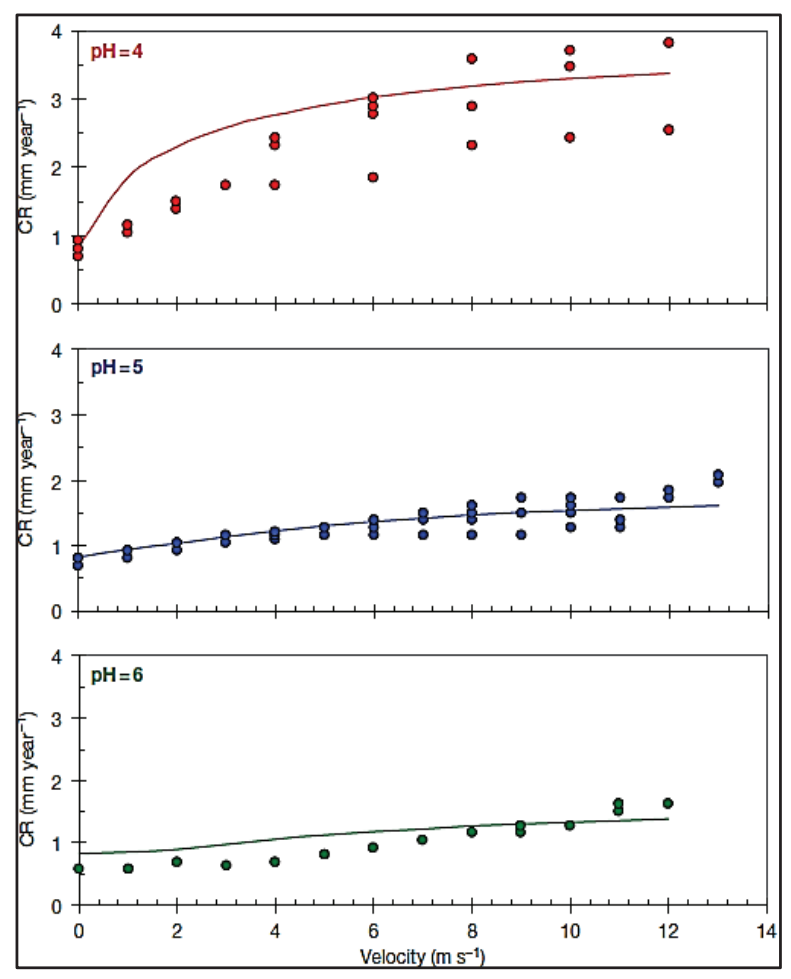

Figure 1. pH Trend in Conventional Well (Nesic, 2010)

If the $\mathrm{pH}$ is lower than 4 , the effect from corrosion will give a more dangerous result. This is caused by the dominant cathodic reaction is direct $\mathrm{H}^{+}$ion reduction (de Waard, Lotz, \& Dugstad, 1995). At the $\mathrm{pH}$ value is ranging between 5 up to 7 , the effect from corrosion will start to reduced. However, if the $\mathrm{pH}$ is having value more than 7 , the protective layer will have an intense production which lead to higher risk on plugging (Nesic \& Sun, 2010). This trend is happened and tested in a conventional oil and gas field. However, for the EAOR field, there still no further research result.

\section{B. Corrosion rate modelling}

In make the corrosion rate model with the existence of electricity due to EAOR application, ASTM G1 (G1, 1999) already made the standard equation which is shown in Equation 1 below.

\section{Equation 1. ASTM G1 Equation}

$$
C R=\frac{K s p_{F e(O H) 2} \times M W_{\text {metal }} \times H \bar{U} \times V_{\text {pipe }} \times\left[H^{+}\right]}{A \times \rho_{\text {metal }} \times \Delta t \times K_{H 2 O}}
$$

where $C R$ is corrosion rate $(\mathrm{mm} / \mathrm{y}), A$ is the area between cathode and anode well $\left(\mathrm{m}^{2}\right), \rho_{\text {metal }}$ is metal density $(\mathrm{g} / \mathrm{m}), M W_{\text {metal }}$ is equivalent molecular weight of metal, $H U$ is liquid hold up fraction, $y$ is inner pipe volume $(\mathrm{m}), \Delta t$ exposure trine (days), $\mathrm{K}_{\mathrm{H} 2 \mathrm{O}}$ is $\mathrm{H}_{2} \mathrm{O}$ dissociation constant, $\mathrm{Ksp}_{\mathrm{Fe}(\mathrm{OH}) 2}$ is $\mathrm{Fe}(\mathrm{OH})_{2}$ is solubility product constant in water and $\left[\mathrm{H}^{+}\right]$is concentration of $\mathrm{H}^{+}$ion. In this study, the $\left[\mathrm{H}^{+}\right]$will be calculated using the $\mathrm{pH}$ data which the conversion is shown in Equation 2 below.

\section{Equation 2. pH Conversion Equation}

$$
p H=-\log \left[H^{+}\right]
$$

In calculating the $\mathrm{Ksp}_{\mathrm{Fe}(\mathrm{OH}) 2}$, it is calculated using the Singer and Stumm equation (Singer \& Stumm, 2015). This calculation is converting the Ksp in standard condition which have a value of $8 \times 10^{-16}$ at $25^{\circ} \mathrm{C}$ (Stumm \& Lee, 1961). The $\mathrm{R}$ value is $1.987 \mathrm{cal} / \mathrm{mole}-\mathrm{K}^{\mathrm{o}}$ and the value of $\Delta H$ is $-4639 \mathrm{cal} / \mathrm{mole}$. The equation is shown in Equation 3 below.

\section{Equation 3. Ksp Equation}

$$
\ln \frac{K_{2}}{K_{1}}=-\frac{\Delta H}{R}\left(\frac{T_{1}-T_{2}}{T_{1} \times T_{2}}\right)
$$


The overview for calculation process for this study is shows in the Figure 2.

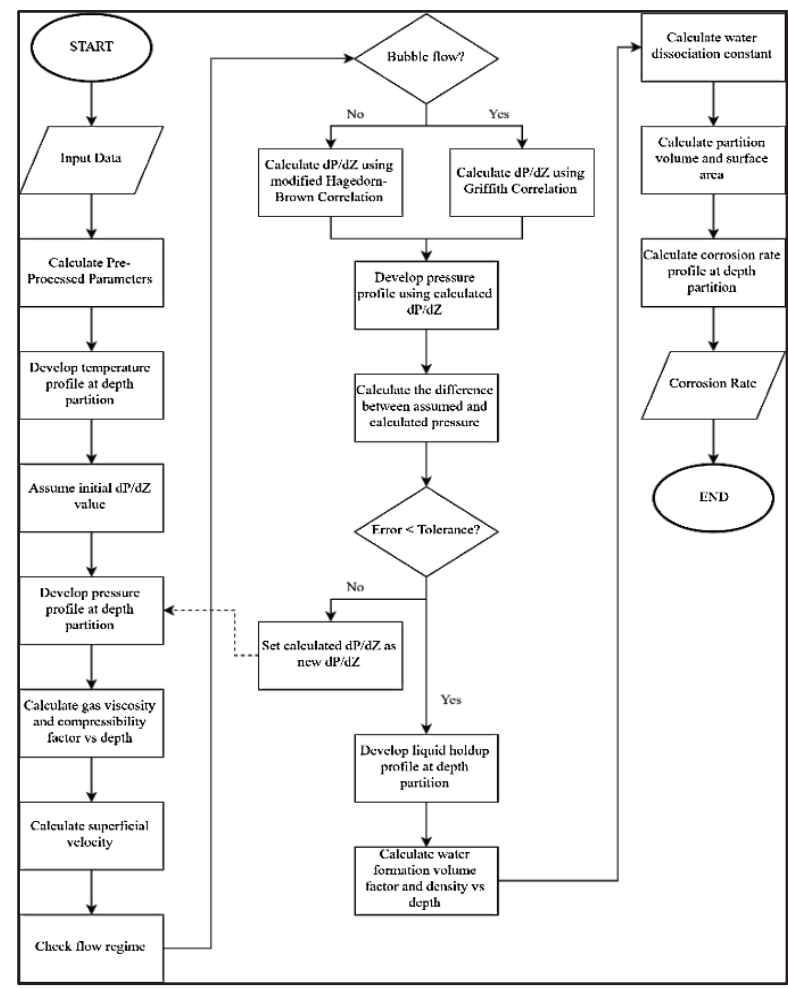

Figure 2. Calculation Process Flowchart

The calculation of liquid hold up fraction (HU) and pressure gradient are specified based on the flow regime, whether the flow regime is linear or bubble flow. If the flow is linear, then it will use modified Hagedorn-Brown correlation that shows below. The classification between these two methods is implemented as it will make a difference in the corrosion rate result. The workflow for modified Hagedorn-Brown is shown in Figure and for Griffith method is shown in Figure 4. Griffith Calculation Flowchart

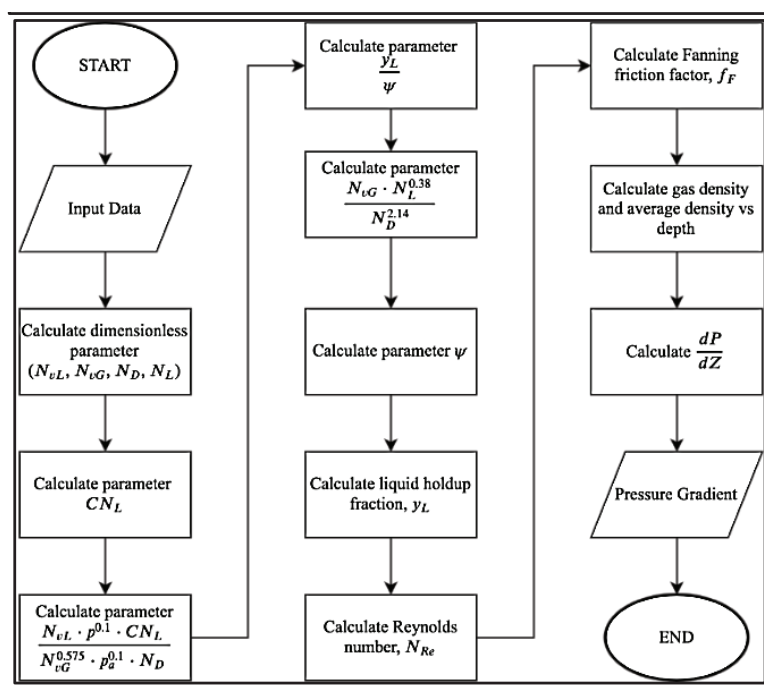

Figure 3. Modified Hagedorn-Brown Calculation Flowchart

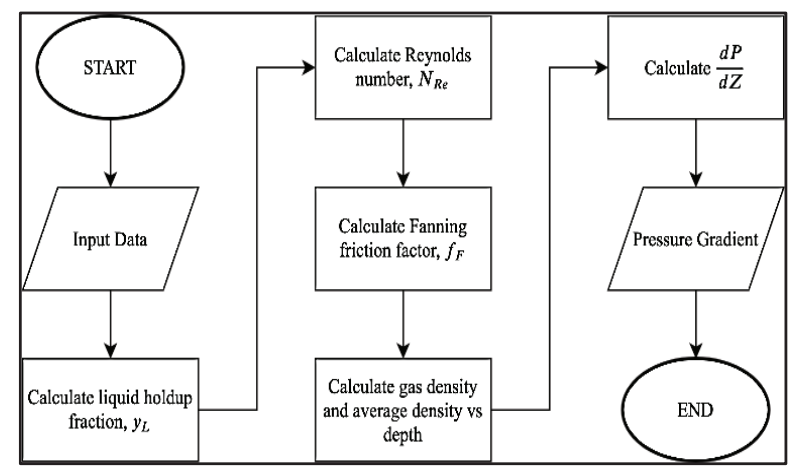

Figure 4. Griffith Calculation Flowchart

\section{Sensitivity analysis}

Sensitivity analysis is a studies to the impact of independent parameters on dependent parameters. The independent parameter will be varied over a range of value and its impact to the result is observed. If the output varies a lot when the input parameter is changed, then the output is sensitive to the change of input value. 
In this study, the sensitivity process will be done with the help of Microsoft Excel software which the observed result will be the impact of $\mathrm{pH}$ on the result of corrosion rate. The result from the analysis could be analysed how the $\mathrm{pH}$ change could impact on the corrosion rate.

\section{METHODS}

\section{A. Data collecting}

Data that is used in this study will come from an oil field that have been implemented the EAOR method in Indonesia. From the field data, there will be an analysis to determine the pair well for EAOR method application. This pair well is between cathode and anode well where the cathode is having a role as the production well an anode is having a role as the injection well. This method is chosen as there are some available well that could be used as the anode and being sacrificed. This pair well selection will have some criteria, such as:

1. Anode well is not used and have a lot of perforation.

2. Distance between anode and cathode is less than 400 meters.

Based on this criteria, the chosen pair well is 8 pairs. From this 8 pair wells, the cathode well is 8 wells and the anode well is 5 wells. From these pair wells, here are some parameters that are used in the calculation.

1. Depth

2. Tubing inner diameter

3. Tubing density

4. Tubing equivalent molecular weight

5. Pipe roughness

6. Oil gravity

7. Oil viscosity

8. Production GLR

9. Gas specific gravity

10. Flowing tubing head pressure

11. Flowing tubing head temperature

12. Flowing temperature at tubing shoe
13. Liquid production rate

14. Water cut

15. Interfacial tension

16. Water salinity

17. Water $\mathrm{pH}$

18. Exposure time

\section{B. Calculation assumptions}

Some assumption that is used in the calculation process in this study are:

1. The fault existence will not be considered in this study.

2. Type of driving force is not being observed.

3. The casing or tubing type in every well is assume to use the API grade K-55.

4. Well connection between anode and cathode is assumed to be fully connected.

5. The existence of other contaminants, such as hydrogen sulphide, oxygen and water formation is assumed not having any effect on the corrosion calculation.

\section{Corrosion rate calculation}

From the chosen pair well, the data will be calculated first using the base line of $\mathrm{pH} 7.5$ using the ASTM G1 equation. The result will be the initial investigation in analysing the $\mathrm{pH}$ effect. The result will be a corrosion rate in millimeter per year.

\section{Sensitivity analysis process}

After determining the base line, the sensitivity analysis process is executed where the $\mathrm{pH}$ will be varied in the range of $6.5-8$. The selection of the range of $\mathrm{pH}$ value is based on the field condition for the case study. The result will show how much impact does the $\mathrm{pH}$ given to the corrosion rate based on the change to the base line. As commonly the highest corrosion rate value is occurred in the well head, in this study, the sensitivity process will analyze the $\mathrm{pH}$ impact on corrosion rate in the well head. 


\section{CASE STUDY}

In this study, to determine the effect of $\mathrm{pH}$ on EAOR installation, a case study is made using an EAOR pilot project field in Indonesia. The case study is using 8 cathode-anode well pairs with specification of 8 cathodes and 5 anodes. The pair well is shown in Table 1 below.

Table 1. List of Well Pairs

\begin{tabular}{|c|c|c|}
\hline Pair & Well Cathode & Well Anode \\
\hline 1 & Cathode-5 & Anode-1 \\
\hline 2 & Cathode-7 & Anode-4 \\
\hline 3 & Cathode-3 & Anode-2 \\
\hline 4 & Cathode-4 & Anode-4 \\
\hline 5 & Cathode-6 & Anode-5 \\
\hline 6 & Cathode- 8 & Anode-5 \\
\hline 7 & Cathode-1 & Anode-3 \\
\hline 8 & Cathode-2 & Anode-3 \\
\hline
\end{tabular}

The $\mathrm{pH}$ value variation in the case study is using range of $6.5-8.0$ which is based on the actual average $\mathrm{pH}$ in the field. The well specification for cathode is shown in Table 2.

Table 2. Cathode Well Specification

\begin{tabular}{|c|c|c|c|c|}
\hline Parameter & C-1 & C-2 & C-3 & C-4 \\
\hline Depth (ft) & 2273.62 & 2119.42 & 2267 & 2444.23 \\
\hline Pipe ID (in) & 5.92 & 5.92 & 4.494 & 4.892 \\
\hline $\begin{array}{c}\text { Pipe Density } \\
\text { (lb/ ft3) }\end{array}$ & 115.85 & 115.85 & 201.04 & 169.66 \\
\hline $\begin{array}{c}\text { Pipe } \\
\text { Roughness } \\
\text { (in) }\end{array}$ & 0.001 & 0.001 & 0.001 & 0.001 \\
\hline $\begin{array}{c}\text { Oil Gravity } \\
\text { (API) }\end{array}$ & 33.88 & 34.3 & 34.9314 & 33.74 \\
\hline $\begin{array}{c}\text { Oil Viscosity } \\
\text { (cP) }\end{array}$ & 3.0322 & 2.73 & 3.6423 & 4.5702 \\
\hline
\end{tabular}

\begin{tabular}{|c|c|c|c|c|}
\hline $\begin{array}{c}\text { Prod. GLR } \\
\text { (scf/ bbl) }\end{array}$ & 39 & 39 & 50 & 121 \\
\hline Gas SG & 0.8556 & 0.8534 & 0.8502 & 0.8563 \\
\hline $\begin{array}{c}\text { Flowing THP } \\
\text { (psi) }\end{array}$ & 21 & 21 & 20 & 21 \\
\hline $\begin{array}{c}\text { Tubing Shoe } \\
\text { Temp (F) }\end{array}$ & 140 & 140 & 140 & 180 \\
\hline $\begin{array}{c}\text { Liquid Prod. } \\
\text { Rate (STB/ d) }\end{array}$ & 36.23 & 298.14 & 263.2 & 329.41 \\
\hline $\begin{array}{c}\text { Water Cut } \\
\text { (\%) }\end{array}$ & 92.85 & 96.87 & 87.61 & 98.14 \\
\hline $\begin{array}{c}\text { Water } \\
\text { Salinity } \\
\text { (ppm) }\end{array}$ & 9404.91 & 17724.6 & 10646.6 & 5787.64 \\
\hline \begin{tabular}{c} 
Water pH \\
\hline $\begin{array}{c}\text { Exposure } \\
\text { Time (days) }\end{array}$
\end{tabular} & 1 & 1 & 1 & 1 \\
\hline
\end{tabular}

\begin{tabular}{|c|c|c|c|c|}
\hline Parameter & C-5 & C-6 & C-7 & C-8 \\
\hline Depth (ft) & 2270.34 & 1578.08 & 2381.89 & 2549.21 \\
\hline Pipe ID (in) & 5.92 & 5.92 & 5.92 & 5.92 \\
\hline $\begin{array}{c}\text { Pipe Density } \\
\text { (lb/ ft3) }\end{array}$ & 115.85 & 115.85 & 115.85 & 115.85 \\
\hline $\begin{array}{c}\text { Pipe } \\
\text { Roughness } \\
\text { (in) }\end{array}$ & 0.001 & 0.001 & 0.001 & 0.001 \\
\hline $\begin{array}{c}\text { Oil Gravity } \\
\text { (API) }\end{array}$ & 34.91 & 34.46 & 32.92 & 33.92 \\
\hline $\begin{array}{c}\text { Oil Viscosity } \\
\text { (cP) }\end{array}$ & 3.9046 & 4.5702 & 3.5439 & 3.1076 \\
\hline $\begin{array}{c}\text { Prod. GLR } \\
\text { (scf/ bbl) }\end{array}$ & 39 & 45.2 & 39 & 39 \\
\hline \begin{tabular}{c} 
Gas SG \\
\hline $\begin{array}{c}\text { Flowing THP } \\
\text { (psi) }\end{array}$
\end{tabular} & 0.8503 & 0.8526 & 0.8606 & 0.8554 \\
\hline $\begin{array}{c}\text { Tubing Shoe } \\
\text { Temp (F) }\end{array}$ & 180 & 136 & 140 & 21 \\
\hline $\begin{array}{c}\text { Liquid Prod. } \\
\text { Rate (STB/ d) }\end{array}$ & 93.8 & 626.3 & 329.41 & 424.43 \\
\hline
\end{tabular}




\begin{tabular}{|c|c|c|c|c|}
\hline $\begin{array}{c}\text { Water Cut } \\
(\%)\end{array}$ & 69.44 & 93.18 & 98.148 & 92.073 \\
\hline $\begin{array}{c}\text { Water } \\
\text { Salinity } \\
\text { (ppm) }\end{array}$ & 11575.3 & 3979 & 7054.97 & 11544.5 \\
\hline Water pH & 8 & 8.2 & 8 & 8 \\
\hline $\begin{array}{c}\text { Exposure } \\
\text { Time (days) }\end{array}$ & 1 & 1 & 1 & 1 \\
\hline
\end{tabular}

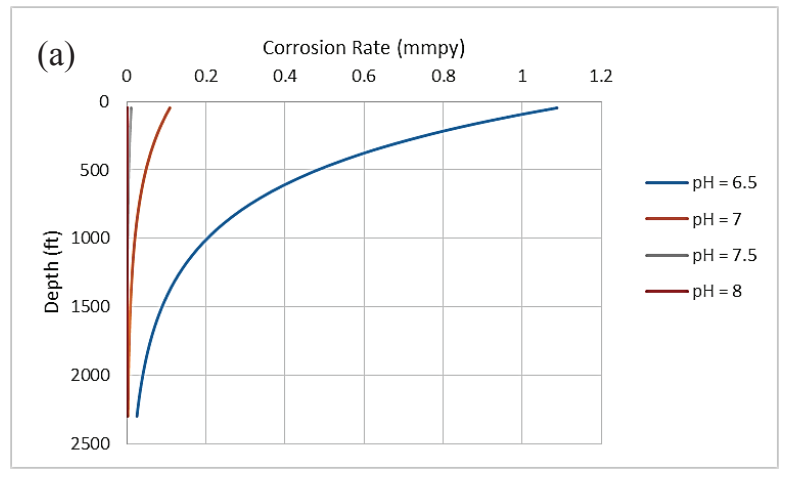

The specification for anode wells are shown in the Table 3.

Table 3. Anode Well Specification

\begin{tabular}{|c|c|c|c|c|c|}
\hline Well Name & A-1 & A-2 & A-3 & $A-4$ & A. 5 \\
\hline Depth $(f t)$ & 2355.64 & 1916.01 & 3254.59 & 1955.38 & 2303.15 \\
\hline Pipe ID (in) & 5.921 & 5.921 & 4.052 & 5.92 & 5.92 \\
\hline Pipe Density (lb/ ftz) & 115.8178687 & 115.8178687 & 247.301538 & 115.8569996 & 115.8569996 \\
\hline Pipe Roughness (in) & 0.001 & 0.001 & 0.001 & 0.001 & 0.001 \\
\hline Oil Gravity (API) & 33.11 & 39.89 & 32.8 & 38.32 & 35.3 \\
\hline Oil Viscosity (cP) & 3.1814 & 1.6948 & 3.5893 & 2.0192 & 2.7521 \\
\hline Prod. GLR (sgf/bbl) & 39 & 39 & 39 & 39 & 39 \\
\hline Gas SG & 0.8596 & 0.8256 & 0.8607 & 0.8333 & 0.8483 \\
\hline Flowing THP (psi) & 14 & 21 & 21 & 21 & 21 \\
\hline Tubing Shoe Temp $\langle F\rangle$ & 136 & 140 & 140 & 140 & 140 \\
\hline $\begin{array}{l}\text { Liquid Prod. Rate } \\
\text { (STB/d) }\end{array}$ & 22.01 & 93.8 & 375 & 347.2 & 347.2 \\
\hline Water Cut $(9 \%)$ & 91.4 & 96.875 & 93.78 & 98.01 & 98.01 \\
\hline Water Salinity (ppm) & 20256.2 & 31108.6 & 7596.28 & 36534.4 & 13083.8 \\
\hline Water pH & 8.2 & 8.2 & 8 & 8.5 & 8 \\
\hline Exposure Time (days) & 1 & 1 & 1 & 1 & 1 \\
\hline
\end{tabular}

Then, these data are being processed by Equation 1 with $\mathrm{pH}$ variation that have been stated before. The result are used to determine the trend of $\mathrm{pH}$ impact in EAOR field.

\section{RESULTS AND DISCUSSION}

With the variation of $\mathrm{pH}$ between $6.5-8.0$, the corrosion rate in cathode are shown in the Figure 5 below.
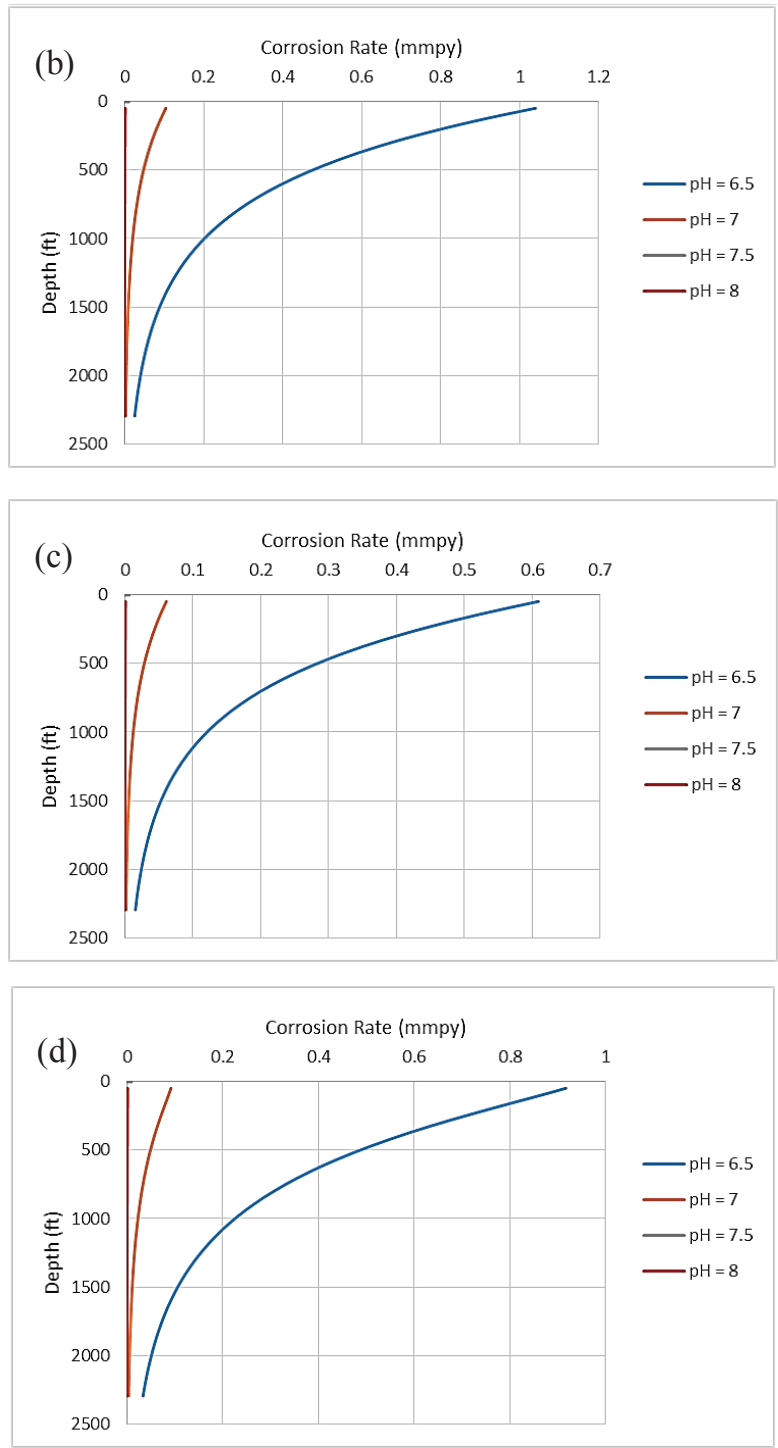

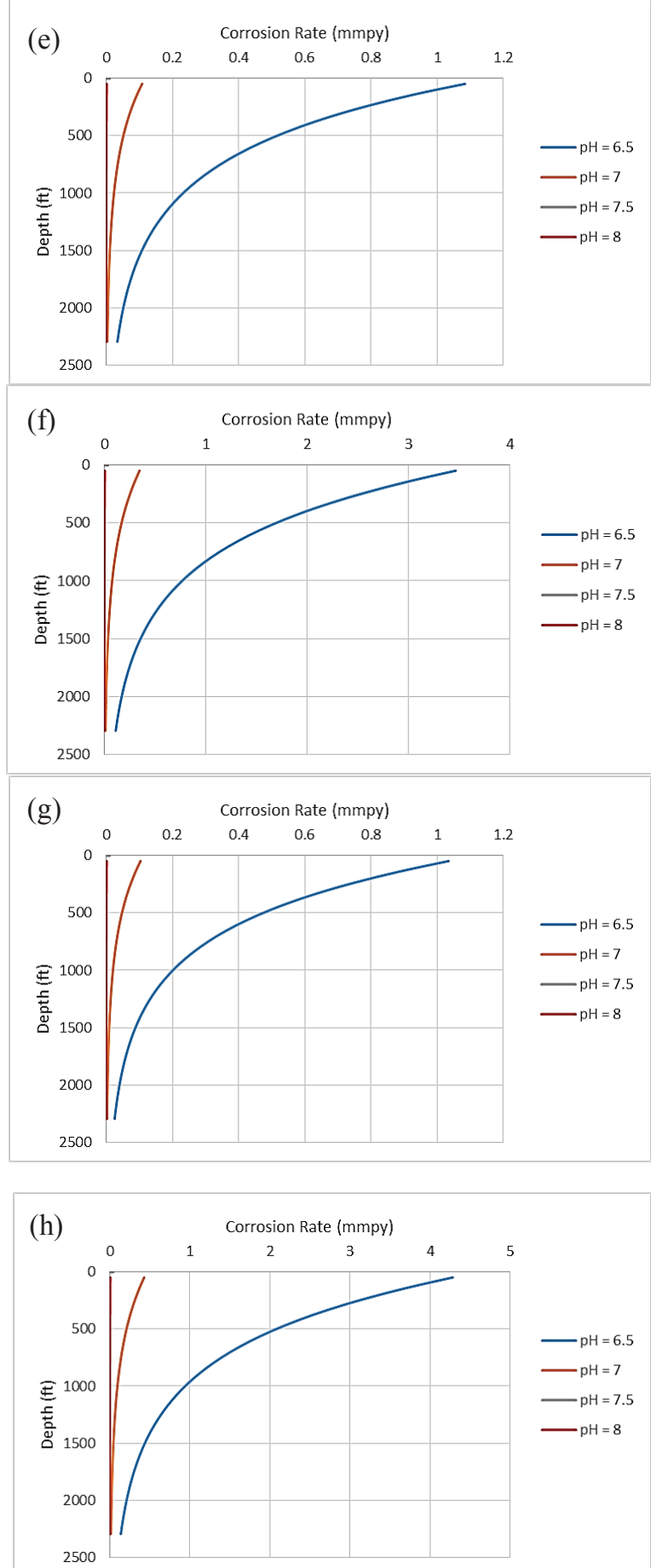

Figure 5. Cathode Analysis Result, (a) C-1, (b) C-2, (c) C-3, (d) C-4, (e) C-5, (f) C-6, (g) C-7, (h) C-8
The corrosion rate result in anode are shown in the Figure 6.
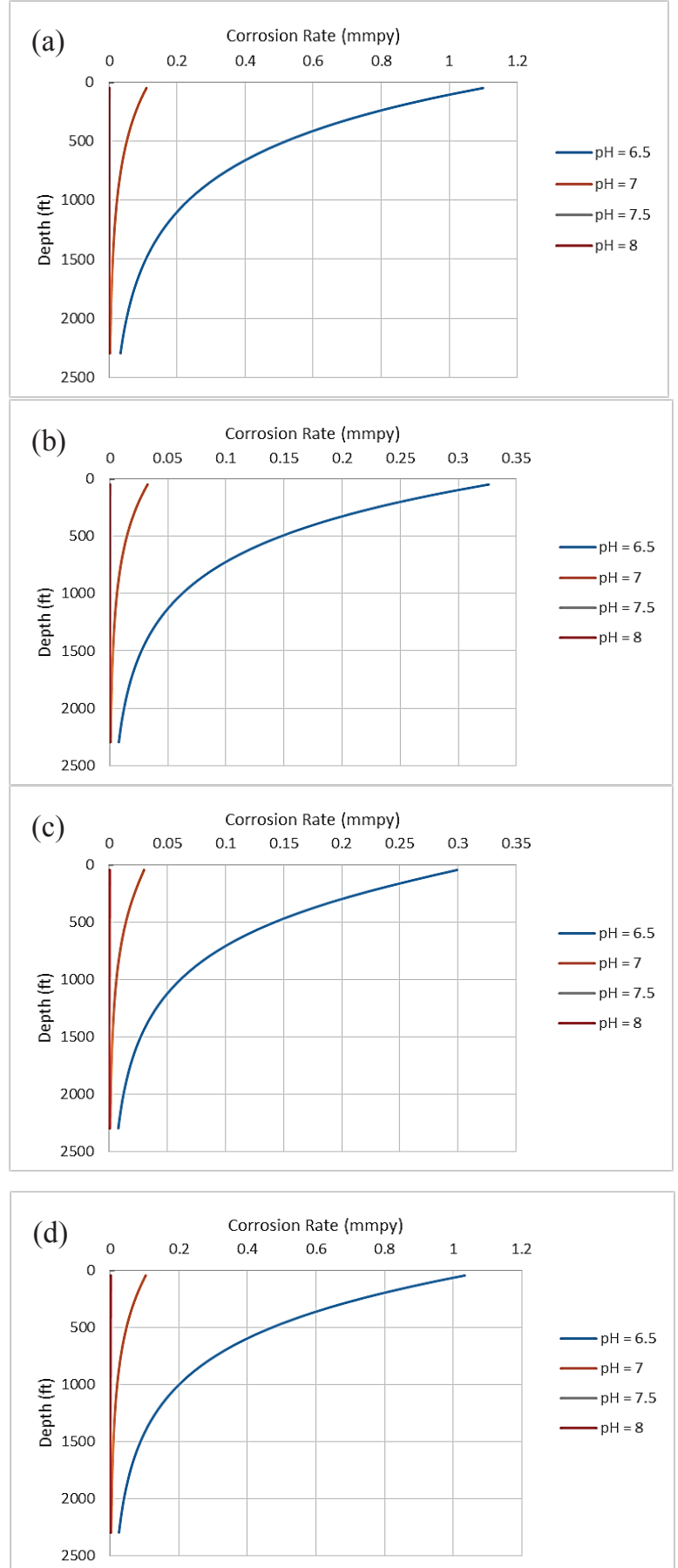


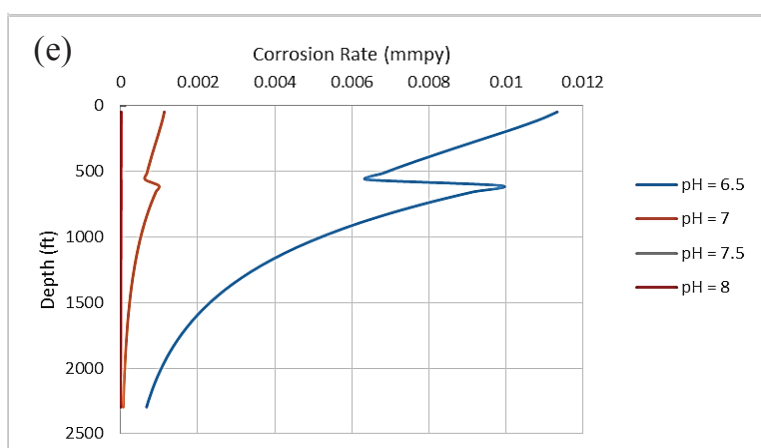

Figure 6. Anode Analysis Result, (a) A-1, (b) A-2, (c) A-3, (d) A-4, (e) A-5

The result depicted on Figure 5 and Figure 6 shows that $\mathrm{pH}$ change will also give an impact to the corrosion rate in EAOR well. In EAOR well, the corrosion rate will reduce with $\mathrm{pH}$ increase. This trend is similar with the conventional well. However, the trend shows that in $\mathrm{pH}$ higher than 7 , there is no big difference in the corrosion rate result. It shows a difference that in the conventional well, corrosion rate should have a big difference due to overproduction of protective layer.

The other difference is that the corrosion rate value change in EAOR well because $\mathrm{pH}$ change is following the logarithmic trend. This is reasonable as the corrosion rate calculation in EAOR well is using the concentration of ion $\mathrm{H}^{+}$which has a logarithmic relation with $\mathrm{pH}$.

An uncommon result in depth $600 \mathrm{ft}$ from well A-5 is happened due to the existence of bubble in the flow which make the liquid holdup calculation is changed from modified Hagedorn-Brown to Griffith. Even though there are bubbles existing in the flow, the corrosion rate trend due to $\mathrm{pH}$ change is still the same.

\section{CONCLUSION}

The result of this study shows that $\mathrm{pH}$ change will also give an impact for corrosion rate in Electrical Assisted Oil Recovery (EAOR) well. The $\mathrm{pH}$ increase will make the corrosion rate value decreased. However, there are no any evidence that $\mathrm{pH}$ with value larger than 7 will make an effect to the corrosion rate trend value.

In addition, the corrosion rate trend due to $\mathrm{pH}$ change is having a logarithmic trend. This is caused by the consideration of ion $\mathrm{H}^{+}$ concentration on the corrosion rate calculation which has a logarithmic relation with $\mathrm{pH}$.

\section{REFERENCES}

Amba, S., Chilingar, G., \& Beeson, C. (1964). Use of Direct Electrical Current for Increasing the Flow Rate of Reservoir Fluids During Petroleum Recovery. Petroleum Society of Canada. de Waard, C., Lotz, U., \& Dugstad, A. (1995). Influence of Liquid Flow Velocity on CO2 Corrosion: A Semi-Empirical Model. The NACE International Annual Conference and Corrosion Show (p. 128). Texas: NACE International. G1, A. (1999).

Kermani, M., \& Harrop, D. (1996). The Impact of Corrosion on Oil and Gas Industry. SPE Journal Production \& Facilities, 03.

Nesic, S., \& Sun, W. (2010). Corrosion in Acid Gas Solutions. Ohio: Elsevier B.V.

Singer, P., \& Stumm, W. (2015). The Solubility of Ferrous Iron in CarbonateBearing Waters. Journal of American Water Works, 198-202.

Smil, V. (2017). Energy and Civilization. Massachusetts: MIT Press.

Stumm, W., \& Lee, G. (1961). Oxygenation of Ferrous Iron. Industrial \& Engineering Chemistry, 143-146.

Taxen, C., \& Kimab, S. (2011). Possible Effects of External Electrical Fields on The Corrosion of Copper in Bentonite. Swedish Nuclear Fuel and Waste Management . 